\title{
Assessment on the Management Practices among Teaching and Non-Teaching Staff of an Academic Institution Managed by a Primary Cooperative in the Philippines: The Case of Lyceum De Cebu
}

\author{
Juneth Lourdes Fiel-Miranda ${ }^{1}$, CPA, D.M., Asterio T. Miranda ${ }^{2 *}$, Jr. Phd \\ ${ }^{I}$ Associate Professor, Keimyung Adams College, International Business Department, Keimyung University. \\ ${ }^{2}$ Associate Professor, Department of Taxation, College of Business Administration, Keimyung University, \\ Republic of Korea
}

*Corresponding Author: Asterio T. Miranda, Associate Professor, Department of Taxation, College of Business Administration, Keimyung University, Republic of Korea

\begin{abstract}
This study sought to determine the extent of implementation of the basic management functions manifested in Lyceum de Cebu in order to recommend proposal for enhancement to the school's administration. Specifically, the study required the teaching and non-teaching personnel to assess their extent of manifestation in the implementation of management functions such as planning, organizing, leading and controlling; determined the significant differences in the assessments made by the teaching and non-teaching staff of Lyceum de Cebu as to the extent of implementation of the management functions.

The descriptive survey method was used in this study which utilized researcher made questionnaires as the main instruments of data collection and were complemented with unstructured interviews to verify the responses given by the 26 total respondents of the study composed of 20 teaching and 6 non-teaching staff of Lyceum de Cebu. A panel of experts determined the validity of the instruments.

The assessments made by the teaching and non-teaching personnel as to the extent of manifestation of the implementation of the management functions in Lyceum de Cebu revealed that in terms of the planning and organizing functions, these were both manifested to a great extent by the teaching staff and to a very great extent by the non-teaching staff, respectively. For the organizing function, it was manifested to a great extent by the teaching staff and to a very great extent by the non-teaching personnel. With regard to the leading and controlling functions, these were manifested to a great extent by both groups of respondents.

The Fisher's t-test of differences revealed that there were no significant differences in the assessments made by the teaching and non-teaching personnel on the extent to which the management functions were manifested in Lyceum de Cebu.
\end{abstract}

Keywords: Management practices; Primary Cooperative; Proposal for Enhancement

\section{INTRODUCTION}

The traditional concept of a school setting was one where the administrators were focused on predictive cause and effect models of human learning. Managing the institution then was anchored on the precept of reducing it to discrete observable and measurable parts. School leaders believed that by understanding the parts, they would be able to see the whole and that perspective would lead to synthesis.

Lyceum de Cebu formerly known as Cebu CFI Coop Learning Center was operated on the basis of such precept. However, with the passage of time, the administrators came to realize that the human system is not predictable, change is not direct and learning is evolving and not patterned. As a result, the former felt the need to create an innovative learning environment that enables all stakeholders of the school to direct their efforts toward greater vigor and coherence in creating a collaborative and dynamic approach to learning.

This realization has paved the way for the administrators to reflect on their existing management practices and how they can align these activities in creating a learning culture that redirects and provides a venue for novelty and personalized learning. 
With this perspective of undertaking, the need for creating an environment that supports the fullest development of the human capacity in Lyceum de Cebu, this study was conducted.

\subsection{Objectives of the Study}

This study was designed to determine the extent of implementation of the basic management functions manifested in Lyceum de Cebu in order to recommend proposals for enhancement to the school's administration. The assessment was focused on finding out the extent of manifestation among the teaching and non-teaching personnel in the implementation of the management functions in Lyceum de Cebu as to planning, organizing, leading and controlling. It sought to determine the degree of significant differences in the assessments made between the teaching and non-teaching staff of Lyceum de Cebu as to the extent of implementation of the management functions. The proposals for enhancement for recommendation to the administration of Lyceum de Cebu to improve the implementation of its management functions were determined based on the findings of the stud

\section{THEORETICAL BACKGROUND}

This study is based on the theory advanced by Murphy who said that the "mission of educational leadership has changed from knowing what to do in order to control and manage to knowing how to live in order to unleash the synergy of the system." This is both the administrators' challenge and opportunity.

School management has never been more crucial as it is today. It is imperative in these complex times to reassess the quality of management practices prevailing in the academic institution. It is the primary responsibility of the school administrators to develop the institution's capacity to envision a desired state of affairs that induces commitment to continuous improvement (Fullan, 2006). Continually improving any organization is a very difficult and often stressful undertaking, when compared to managing the status quo; however, anxiety and resistance can be decreased and overcome when the objectives, the frames of reference, and the reforms are clarified and have a sense of political support. Thus, the thrust now is for school administrators to rethink education and create new, more effective paradigms of management to improve the entire system.

The first component of the management practices considered in this study is the planning process.

Planning is the process of determining exactly what the organization will do to accomplish its objectives. In more formal terms, it is the systematic development of action programs aimed at reaching agreed business objectives by the process of analyzing, evaluating and selecting among the opportunities which are foreseen (Jones, 2005).

Planning is the primary management function - the one that precedes and is the basis for organizing, influencing and controlling functions of managers. Only after managers have developed their plans can they determine how they want to structure the organization. This is a critical management activity regardless of the type of organization being managed.

Planning occurs at all levels of the organization. Corporate level planning focuses on resource allocation issues between several divisions within the same organization. Business level planning concerns how to achieve business/school objectives within the context of overall corporate objectives. Functional level planning supports specific aspects of the business level strategy (Dumler, 2008).

Planning puts purpose into action. Without planning, organizations can only react to changes in the environment, technology and customer demands. With careful planning, an organization can both anticipate and influence upcoming events.

Three characteristics of the modern organization underscore the need for planning: 1) cycle time reduction, 2) organizational complexity, and 3) global competition (Dumler, 2008).

Cycle time Reduction (CTR) has become a key goal for organizations. Cycle time refers to the length of time required to complete a process and to be ready to begin anew. High performing, competitive organizations have realized that although economy of scale - a decrease in per unit manufacturing cost as a result of increased size of production facilities - was formerly the key to success, today, economy of time is important. Organizations of all types are putting significant planning effort into improving functionality, reducing cycle time, and accommodating the needs of people who interact with the organization.

Mergers, acquisitions, restructuring and strategic alliances all make organizations more complicated 
and difficult to manage. This complexity means that few organizational decisions can be made independently of other decisions. The more products (both tangible and intangible) an organization produces and the more markets it competes, the internal complexity of the organization also increases. Senge (2007) observed that to remain competitive in the global economy, organizations must learn to be comfortable with uncertainty and complexity. Hence, managers must develop a capacity for thinking clearly and continuously about the unknown future. Planning helps organizations deal with complexity and uncertainty by providing a road map for change. With such a road map, an organization can move with the forces of global competition without straying off course.

The last component is global competition. Change is constant. New rivals enter the global economy each year, often dramatically affecting the existing competition. In a global economy, new customers, new markets, and new competitors can come from across the hemisphere. They are no longer just in our own backyards, and they pose both opportunities and competitive threats for many organizations.

The planning process consists of the following steps (Certo, 2006).

Identify Current Conditions. Before goals and objectives can be established, the current state of the organization must be assessed. In strategic planning, for instance, this assessment includes looking at the organization's resources as well as market trends, economic indicators, and competitive factors. Strategic planning takes a broad view of the organization's internal and external environments.

Determine Goals and Objectives. Since planning focuses on how the management system will reach organizational objectives, a clear statement of the objectives is necessary before planning can begin. In essence, objectives stipulate those areas in which organizational planning must occur.Once current conditions are assessed, goals and objectives, can be set. Managers often use these two terms interchangeably, but distinguishing between them is useful. Goals are defined as future states or conditions that contribute to the fulfillment of the organization's mission (Jones, 2005). Goals express relatively intermediate criteria of effectiveness. They can also be stated in terms of production, efficiency and satisfaction. Objectives are short-term, specific, measurable targets that must be achieved to accomplish organizational goals. For objectives to be valuable, they must be relevant, challenging, and direct employee action and behavior.

List Alternative Ways of Reaching Objectives. Once organizational objectives have been clearly stated, top management should list as many available alternatives as possible for reaching those objectives. These need to be specified prior to implementation, as part of the planning process.Actions are specific, prescribed means that are developed to achieve objectives. Such actions determine success or failure in meeting objectives. Planned courses of action - called strategies are usually differentiated by scope and time frame. In any case, an action plan is directed toward changing a future condition; that is achieving an objective (Rue, 2005).

Develop premises on which to Base Each Alternative. To a large extent, the feasibility of using any one alternative to reach organizational objectives is determined by the premises or assumptions, on which the alternative is based.

Choose the Best Alternative for Reaching Objectives. An evaluation of alternatives must include an evaluation of the premises on which the alternatives are based. This elimination process helps the manager determine which alternative best accomplish organizational objectives.

Implement the Plans. Once plans that furnish the organization with both long range and short range direction have been developed, they must be implemented. Implementation concerns the activities involved in delegating tasks, taking action, and achieving results. Without effective implementation, the various preceding steps of the planning process are pointless (Dumler, 2008).Implementation means using resources to put a plan into action. Three ways to implement plans through others are: authority, persuasion and policies (Daft, 2006). Authority accompanies the position, not the person. In an organization, those in authority have the right to make decisions and to expect that subordinates will comply with those decisions. Authority is often sufficient to implement simple plans, but a complex plan can seldom be implemented through authority alone. Persuasion on the other hand is the process of selling a plan to those who must implement it, communicating relevant information, so that those individuals understand possible implications. Persuasion requires convincing others to accept a plan based on its merits rather than on the manager's authority. Policies. These are written statements reflecting a plan's basic values and providing guidelines for selecting actions to achieve objectives. 
When plans are expected to be rather permanent, policies are developed to implement them.

Once all members of the organization thoroughly understand the basics of planning, they can take steps to implement the planning process in their organization.

The second component of the management function included in this study is the process of organizing.

The organizing function is extremely important to the management system because it is the primary mechanism managers use to activate plans. Organizing creates and maintains relationships between all organizational resources by indicating which resources are to be used for specified activities and when, where and how they are to be used. A thorough organizing effort helps managers minimize costly weaknesses, such as duplication of effort and idle organizational resources.

The five main steps of the organizing process are described as follows (Certo, 2006).

a) Reflecting on plans and objectives. Since planning involves determining how a company will attain its objectives, and organizing involves determining how the organization's resources will be used to activate plans, top management must start to organize by understanding planning.

b) Establish major tasks. Here, the top management must designate major tasks on jobs to be done in the firm based on the functional departments created.

c) Divide major tasks into sub-tasks. Once the functional tasks are ascertained, these will be divided into specific sub tasks which must be performed by the various departments created.

d) Allocate resources and directives for sub-tasks. This fourth step involves determining who will perform the specific tasks and resources are allocated to a specific unit to enable them to attain the individual departmental objectives.

e) Evaluate the results of implemented organizing strategy. In this phase, top management will assess the impact of the action by gathering feedback on how well the strategy is doing. This process should furnish information that can be used to improve the existing organization.

The four components of the classical organizing theory that all organizations should integrate in their organizing functions consider the following:

The first major consideration in any organizing effort is the organizational structure. In any organizing effort, managers must choose an appropriate structure. It refers to the designated relationships among resources of the management system. Its purpose is to facilitate the use of each resource, individually and collectively, as the management system attempts to attain its objective (Certo, 2006). An effective organizational structure does not result from chance, luck or historical accident (Davis, 2008). It is the responsibility of top management to deliberately develop a structure that enhances the organization's overall strategy, taking into consideration factors such as competition and the environment. An organization structure is represented primarily by means of a graphic illustration called the organization chart. Traditionally, an organization chart is constructed in pyramid form, with individuals toward the top of the pyramid having more authority and responsibility than those toward the bottom (Davis, 2008). The relative positioning of individuals within boxes on the chart indicates working relationships, and lines between boxes designate formal lines of communication between individuals. There are two basic types of structure within management systems. Formal and informal (Campling, 2006). Formal structure is defined as the relationships among organizational resources as outlined by management. It is represented primarily by the organization chart. Informal structure on the other hand refers to the pattern of relationships that develop because of the informal activities of organizational members. It evolves naturally and tends to be molded by individual norms, values and social relationships (Galbraith, 2006). Essentially, an organization's informal structure is the system or network of interpersonal relationships that exists within, but is not usually identical to the organization's formal structure. The most common method of instituting formal relationships among resources is to establish departments. Basically, a department is a unique group of resources established by management to perform some organizational tasks. The process of establishing departments, within the management system is called departmentalization (Jones, 2005).

The second major consideration of any organizing effort is how to divide labor. The division of labor 
is the assignment of various portions of a particular task among a number of organization members. Rather than one individual is doing the entire job, several individuals perform different parts of it. Campling (2006) said that the essence of division of labor is that individuals specialize in doing part of the task rather than the entire task. In a division of labor situation, the importance of effective coordination of the different individuals doing portions of the task is obvious. It is a means for achieving any and all organizational objectives (Mooney, 2004). It involves encouraging the completion of individual portions of a task in a synchronized order that is appropriate for the overall task.

The third main consideration of any organizing effort is span of management - the number of individuals a manager supervises. The more individuals a manager supervises, the greater the span of management. Conversely, the fewer individuals a manager supervises, the smaller the span of management (Certo, 2006). The span of management has a significant effect on how well managers carry out their responsibilities. The central concern of span of management is to determine how many individuals - a manager can supervise effectively. To use the organization's human resources effectively, managers should supervise as many individuals as they can best guide toward production quotas. If they are supervising too few people, they are wasting a portion of their productive capacity. If they are supervising too many, they are losing part of their effectiveness.

The fourth main consideration of any organizing effort is scalar relationships - the chain of command. Every organization is built on the premise that the individual at the top possesses the most authority and that other individuals' authority is scaled downward according to their relative position on the organization chart (Rue, 2005). The lower a person's position on the organization chart, then, the less authority that person possesses. The scalar relationship, or chain of command, is related to the unity of command. This is the management principle that recommends that an individual have only one boss (Hackman, 2004). If too may bosses give orders, the result will probably be confusion, contradiction and frustration - a sure recipe for ineffectiveness and inefficiency in an organization.

The third management function considered in this study is leading.

Collective action is an integral part of all organizations. Without groups, organizations would have to rely solely on individuals to complete both daily tasks and longer term assignments. One can just imagine many activities would be impossible without the collective efforts of two or more people. It is within this context that the function of leading is deemed important. Leading as a process emphasizes mainly behavioral issues (Certo, 2006). A leader is somebody who cares about and focuses on the people who do the job. There are three primary factors or forces that influence a manger's determination of which leadership behavior to use in making decisions. They are as follows (Yuki, 2002):

Forces in the Manager. Managers should be aware of four forces within themselves that influence their determination of how to make decisions as a leader. The first force is the manager's values, such as the relative importance to the manager of organizational efficiency, personal growth, the growth of subordinates and company profits. The second influencing force is level of confidence in subordinates. In general, the more confidence a manager has in his or her subordinates, the more likely that manager's decision making style will be democratic, or subordinate centered. The third influencing force within the manager is personal leadership strengths. Some managers are more effective in issuing orders than in leading group discussions, and vice versa. Managers must be able to recognize their own leadership strengths and capitalize on them. The fourth influencing force within the manager is tolerance for ambiguity. The move from a boss centered style to a subordinate centered style means some loss of authority about how problems should be solved.

Forces in Subordinates. A manager should be aware of forces within subordinates that influence the manager's determination of how to make decisions as a leader. To lead successfully, the manager needs to keep in mind that subordinates are both somewhat different and somewhat alike. Any cookbook approach to leading all subordinates is therefore impossible.

Forces in the Situation. The last group of forces that influence a manager's determination of how to make decisions as a leader are forces in the leadership situation. The first of such situational force is the type of organization in which the leader works. Organizational factors like the size of working groups and their geographical distribution are especially important influences on leadership style. The second situational form is the effectiveness of a group. To gauge this fora, managers should evaluate such issues as the experience of group members in working together and the degree of confidence they have in their ability to solve problems as a group. As a general rule, managers should assign 
decision making responsibilities only to effective work groups. The third situational force is the problem to be solved. Before deciding to act as a subordinate-centered leader, a manager should be sure that the group has the expertise necessary to make a decision about the problem in question. If it does not, the manager should move toward more boss centered leadership.

The fourth management function involved in this study is controlling.

As the size and complexity of modern organizations grow, so does the problem of control in organizations. Control is a fundamental management responsibility closely linked with the planning and organizing processes. Control is both a process and an outcome (Dumler, 2008). In traditional terms, the controlling function includes all activities that a manager undertakes in attempting to ensure that actual results conform to planned results.

Controlling according to Mockler (2001) is a systematic effort by business management to compare performance to predetermined standards, plans or objectives to determine whether performance is in line with these standards and presumably to take any remedial action required to see that human and other corporate resources are being used in the most effective and efficient way possible in achieving corporate objectives. Controlling can be a detailed and intricate function, especially as the size of an organization increases. But like many management functions, control can be implemented and manifested in different ways.

There are three main steps in the controlling process (Aldag, 2006).The first is measuring performance. Before managers can determine what must be done to make an organization more effective and efficient, they must measure current organizational performance. But before they can take such a measurement, they must establish some unit of measure that gauges performance and observe the quantity of this unit generated by the item whose performance is being measured. How to Measure. A manager who wants to measure the performance of a certain employee, first must establish units of measure that represent employee performance, and the number of each of these units accomplished by each employee. The process of determining both the units of measure and the number of units associated with each employee furnishes the manager with a measure of performance. What to Measure. Managers must always keep in mind that there is a wide range of organizational activities that can be measured as part of the control process. The degree of difficulty in measuring various types of organizational performance, of course, is determined primarily by the activity being measured.

The second is comparing measured performance to standards. Once managers have taken a measure of organizational performance, their next step in controlling is to compare this measure against some standard. A standard is the level of activity established to serve as a model for evaluating organizational performance. The performance evaluation can be for the organization as a whole or for some individuals working within the organization. In essence, standards are the yardsticks that determine whether organizational performance is adequate or inadequate.

The third and last step in the controlling function is taking corrective action. After actual performance has been measured and compared with established performance standards, the next step in the controlling process is to take corrective action if necessary. Corrective action is a managerial activity aimed at bringing organizational performance up to the level of performance standards. In other words, corrective action focuses on correcting organizational mistakes that are hindering organizational performance. Before taking any corrective action, however, managers should make sure that the standards they are using are properly established and that their measurements of organizational performance are valid and reliable. Firstly, managers must be able to recognize problems. At first glance, it seems a fairly simple preposition that managers should take corrective action to eliminate problems - factors within an organization that are barriers to organizational goal attainment. In practice however, it often proves difficult to pinpoint the problem causing some undesirable organizational effect. Secondly, managers must be able to recognize symptoms. Before attempting to take corrective action, the manager must determine whether the worker's failure to perform is a problem in itself or a symptom, a sign that a problem exists. Once the problem has been properly identified, corrective action can focus on one or more of the three primary management functions of planning, organizing and influencing. That is, corrective action can include such activities as modifying past plans to make them more suitable for future organizational endeavors, and others. Finally, to make controlling successful, Certo (2006) took into account the following factors:

a) Specific organizational activities being focused on. Managers should make sure the various facets 
of the control process are appropriate to the control activity under consideration.

b) Different kinds of organizational goals. Control can be used for such different purposes as standardizing performance, protecting organizational assets from theft and waste, and standardized product - quality. Managers should remember that the control process can be applied to many different facets of organizational life and that if the organization is to receive maximum benefit from controlling, each of these facets must be emphasized.

c) Timely corrective action. Some time will necessarily elapse as managers gather control related information, develop necessary reports based on this information, and decide what corrective action should be taken to eliminate a problem. However, managers should take the corrective action as promptly as possible to ensure that the situation depicted by the information gathered has not changed. Unless corrective actions are timely, the organizational advantage of taking them may not materialize.

d) Communication of the mechanics of the control process. Managers should take steps to ensure that people know exactly what information is required for a particular control process, how that information is to be gathered and used to compile various reports, what the purposes of the various reports, actually are, and what corrective actions are appropriate given those reports.

In short, for control to be successful, all individuals involved in controlling must have a working knowledge of how the control process operates.

\section{RESEARCH METHODOLOGY}

The descriptive survey method was used in this study. Researcher-made questionnaires were adopted as the main instruments of data collection and were complemented with unstructured interviews to verify the responses given by some of the respondents. The respondents of the study were the 20 teaching and 6 non-teaching staff of Lyceum de Cebu assigned in the various levels and offices of the school. The researcher-made instruments were utilized in this study- the Survey questionnaire on the management functions. A panel of experts determined the validity of the instruments.

The survey questionnaire contained questions concerning the extent to which the four basic management functions are implemented and manifested in Lyceum de Cebu. Each query is followed by a number of responses. Corresponding to each response are four numeric scales. They have the qualitative scale with the following meanings:

4 - Very Great Extent (VGE) - means that the management function is practiced and manifested in all instances.

3 - Great Extent (GE) - means that the management function is practiced and manifested in majority of the instances.

2 - Less Extent (LE) - means that the management function is practiced and manifested in some instances.

1 - Never $(\mathrm{N})$ - means that the management function is not practiced and manifested in any instances.

In order to ensure the functionality of the instruments, the researcher administered the questionnaires to four (4) probationary employees of Lyceum de Cebu as dry run respondents and were not involved in the actual study. The incidence of non response to any question and the trend of responses were noted. Since the dry run respondents were able to answer all the questions with a reasonable range of variation, the instruments were then finalized.

Permission to conduct this study was sought from the President of Lyceum de Cebu, after which the proponent ask the assistance of the various heads of the school in the administration of the survey instruments. These were done during the department meeting of each unit and the researchers made themselves available to explain the purpose of the study and to answer the queries that were raised by the respondents.

The accomplished questionnaires were collected and the responses to each instrument were tallied. The data were then processed and tabulated. The weights assigned to the scales were noted. The weighted mean of each item was determined. The following formula was applied:

$$
\mu=\frac{\sum f x}{N}
$$


Where:

$\begin{array}{lll}\mu & = & \text { weighted mean } \\ \Sigma & = & \text { summation } \\ f & = & \text { the number of responses under each scale } \\ \chi & = & \text { the weight assigned to each scale } \\ \mathrm{N} & = & \text { number of respondents }\end{array}$

The null hypothesis was tested at the 0.05 level of significance, by using the Fisher's T-test of differences between the means of the two groups of respondents.

\section{FINDINGS}

This study was concerned with determining the extent to which Lyceum de Cebu practiced basic management functions. The functions included planning, organizing, leading and controlling.

\subsection{Planning Functions}

Data on the extent to which planning functions are implemented in Lyceum de Cebu are presented in Table 1. The factor mean of 3.41 derived from the group average of 3.21 from the teaching staff and 3.61 from the non-teaching staff revealed that basic planning functions were adopted and practiced to a very great extent.

Specifically, all sectors of the school to a great extent $(\mu=3.26)$ were allowed to participate in the formulation of the school's objectives. The administration upholds the dictum - that people are more committed to the concretization of the goal if they know that they are part of its conceptualization.

The composite mean of 3.78 reveals the fact that the school to a very great extent was able to articulate the vision, mission and goals in a clear statement. It can be construed from the findings that the school's vision, mission and goals describes the institution's fundamental purpose or rationale for its existence and the ways of achieving it.

To a very great extent $(\mu=3.46)$, the school was able to clarify the individual roles of all sectors leading to the attainment of its goals. This means that the organization's goals are clearly communicated to all its members galvanizing their support and holding them accountable for their actions and decisions.

The composite mean of 3.38 indicates the fact that the school to a very great extent was able to identify its present and future opportunities and how to take advantage of them. It can be inferred from the findings that the Lyceum de Cebu is able to foresee the outcomes the organization desires to achieve over the short, intermediate and long term horizon.

Table1. Planning Functions

\begin{tabular}{|c|c|c|c|c|c|c|}
\hline \multirow[b]{2}{*}{ INDICATORS } & \multicolumn{2}{|c|}{ Teaching Staff } & \multicolumn{2}{|c|}{ Non-Teaching Staff } & \multicolumn{2}{|c|}{ Composite } \\
\hline & Mean & Int. & Mean & Int. & Mean & Int. \\
\hline $\begin{array}{l}\text { 1. Formulating the school's objectives is done } \\
\text { and participated by all sectors. }\end{array}$ & 3.20 & GE & 3.33 & VGE & 3.26 & GE \\
\hline $\begin{array}{l}\text { 2. Articulating the vision, mission and goals of } \\
\text { the school in a clear statement. }\end{array}$ & 3.55 & VGE & 4.00 & VGE & 3.78 & VGE \\
\hline $\begin{array}{l}\text { 3. Clarifying the individual roles of all sectors of } \\
\text { the school leading to the attainment of its goals. }\end{array}$ & 3.25 & GE & 3.67 & VGE & 3.46 & VGE \\
\hline $\begin{array}{l}\text { 4. Identifying present and future opportunities } \\
\text { of the school and how to take advantage of them. }\end{array}$ & 3.10 & GE & 3.67 & VGE & 3.38 & VGE \\
\hline $\begin{array}{l}\text { 5. Emphasizing internal and external factors in } \\
\text { the planning process. }\end{array}$ & 3.00 & GE & 3.33 & VGE & 3.17 & GE \\
\hline $\begin{array}{l}\text { 6. Describing how the plans will lead to the } \\
\text { realization of the goals in a simple manner. }\end{array}$ & 3.15 & GE & 3.67 & VGE & 3.41 & VGE \\
\hline FACTOR MEAN & 3.21 & GE & 3.61 & $\mathrm{E}$ & 3.41 & VGE \\
\hline
\end{tabular}

$n=26$ 
Legend:

\begin{tabular}{ll}
\multicolumn{1}{c}{ Range } & $\underline{\text { Interpretation }}$ \\
$3.26-4.00$ & Very Great Extent (VGE) \\
$2.51-3.25$ & Great Extent (GE) \\
$1.76-2.50$ & Less Extent (LE) \\
$1.00-1.75$ & Never (N)
\end{tabular}

Emphasizing internal and external factors in the planning process was made to a great extent as shown by the composite mean of 3.17. Planning in Lyceum de Cebu entails a careful analysis of the factors present in the environment that creates opportunities or threats to the school.

Lastly, describing how the plans will lead to the realization of the goals of the school in a simple manner was adhered to a very great extent $(\mu=3.41)$. In other words, the school saw to it that its aspirations as contained in the plans were enunciated to ensure that all the school's stakeholders can internalize it.

\subsection{Organizing Function}

Table 2 highlights the extent to which activities pertaining to organizing are implemented in Lyceum de Cebu. The factor mean of 3.21 taken from the group mean of 3.08 from the teaching staff and 3.34 from the non-teaching staff indicated that Lyceum de Cebu manifested basic organizing functions to a great extent.

Specifically, the school to a very great extent $\mu=3.29$ structured its human and material resources to ensure that they were consistent with the vision, mission and goals of the school. It can be inferred from the finding that the school provides a framework of proper utilization of its resources to attain and realize its vision, mission, and objectives.

The composite mean of 3.29 indicates that the school to a very great extent defined the duties and responsibilities of all its stakeholders in a simple and clear manner by providing a job description for each function to be performed. In other words, there is a clear delineation of functions to avoid overlapping of duties and possible conflicts.

The philosophy of unity of command is upheld to a very great extent in Lyceum de Cebu as shown by the composite mean of 3.41. This implies that to ensure that everybody knows to whom they are accountable, each employee reports only to one head.

Table2. Organizing Functions

\begin{tabular}{|c|c|c|c|c|c|c|}
\hline \multirow[b]{2}{*}{ INDICATORS } & \multicolumn{2}{|c|}{ Teaching Staff } & \multicolumn{2}{|c|}{ Non-Teaching Staff } & \multicolumn{2}{|c|}{ Composite } \\
\hline & Mean & Int. & Mean & Int. & Mean & Int. \\
\hline $\begin{array}{l}\text { 1. Structuring the human and material resources } \\
\text { to ensure that they are consistent with the } \\
\text { vision, mission and goals of the school. }\end{array}$ & 2.90 & GE & 3.67 & VGE & 3.29 & VGE \\
\hline $\begin{array}{l}2 \text { Defining duties and responsibilities in a clear } \\
\text { and simple manner through the provision of job } \\
\text { description. }\end{array}$ & 3.25 & GE & 3.33 & GE & 3.29 & VGE \\
\hline 3. Promoting the unity of command. & 3.15 & GE & 3.67 & GE & 3.41 & VGE \\
\hline $\begin{array}{l}\text { 4. Coordinating all activities and efforts in the } \\
\text { school in a synchronized manner. }\end{array}$ & 3.15 & GE & 3.67 & GE & 3.41 & VGE \\
\hline $\begin{array}{l}\text { 5. Encouraging specialization in the performance } \\
\text { of a specific task for each employee }\end{array}$ & 3.05 & GE & 3.00 & GE & 3.02 & VGE \\
\hline $\begin{array}{l}\text { 6. Limiting the number of employees being } \\
\text { supervised by a certain department head. }\end{array}$ & 2.95 & GE & 2.67 & $\mathrm{~S}$ & 2.81 & GE \\
\hline FACTOR MEAN & 3.08 & GE & 3.34 & VGE & 3.21 & GE \\
\hline
\end{tabular}

$n=26$

Legend:

$\begin{array}{ll}\text { Range } & \frac{\text { Interpretation }}{3.26-4.00} \quad \text { Very Great Extent (VGE) }\end{array}$




$$
\begin{array}{ll}
2.51-3.25 & \text { Great Extent (GE) } \\
1.76-2.50 & \text { Less Extent (LE) } \\
1.00-1.75 & \text { Never }(\mathrm{N})
\end{array}
$$

To a very great extent $(\mu=3.41)$, all activities and efforts of the school were coordinated in a synchronized manner. This was to ensure that all employees can perform more efficiently if all functions were complemented and arranged in a systematic flow.

Work specialization is encouraged in Lyceum de Cebu to a great extent $(\mu=3.02)$ by assigning a specific task to each employee. It can be construed from the findings that the work in the school is divided into specific jobs so that the employees will be more efficient in terms of their performance and the result is better quality output.

Lastly, the school to a great extent $(\mu=2.81)$ limits the number of employees being supervised by a certain head. This was adhered to enable the supervisor to monitor his/her subordinates better.

\subsection{Leading Functions}

Data on the extent to which practices pertaining to leading function were manifested in Lyceum de Cebu are presented in the table 4 . The factor mean of 2.94 obtained from the group mean of 2.77 from the teaching staff and 3.11 from the non-teaching staff showed that such practices were adopted to a great extent.

Specifically, the employees were provided to a great extent with the necessary resources that will help translate efforts into performance $(\mu=3.23)$. This means that the administration of the school upheld the principle that one sure way to encourage work-related behavior is to ensure that their people are equipped with the essential materials needed in their jobs.

The composite mean of 3.01 shows that the school to a great extent maintains a reward system that gives due recognition to the employees' exemplary performance.

Table3. Leading Functions

\begin{tabular}{|l|l|l|l|l|l|l|l|}
\hline \multicolumn{2}{|c|}{ INDICATORS } & \multicolumn{2}{|c|}{ Teaching Staff } & \multicolumn{2}{|c|}{ Non-Teaching Staff } & \multicolumn{2}{c|}{ Composite } \\
\cline { 2 - 9 } & Mean & Int. & Mean & Int. & Mean & Int. \\
\hline $\begin{array}{l}\text { 1. Providing employees with the necessary } \\
\text { resources that will help translate efforts into } \\
\text { performance. }\end{array}$ & 2.80 & GE & 3.67 & VGE & 3.23 & GE \\
\hline $\begin{array}{l}\text { 2. } \\
\text { Maintaining a reward system that gives due } \\
\text { recognition to exemplary performance. }\end{array}$ & 2.70 & GE & 3.33 & GE & 3.01 & GE \\
\hline $\begin{array}{l}\text { 3. Using the organizational structure to encourage } \\
\text { effective followership. }\end{array}$ & 3.05 & GE & 3.33 & GE & 3.19 & GE \\
\hline $\begin{array}{l}\text { 4. Allowing subordinates to participate in } \\
\text { decision making on matters which affect the } \\
\text { former. }\end{array}$ & 2.85 & GE & 3.00 & GE & 2.93 & GE \\
\hline $\begin{array}{l}\text { 5. Empowering employees to make decisions } \\
\text { within prescribed limits. }\end{array}$ & 2.60 & GE & 2.67 & GE & 2.64 & GE \\
\hline $\begin{array}{l}\text { 6. Soliciting all the school members' inputs } \\
\text { before final decisions }\end{array}$ & $2 . .60$ & GE & 2.67 & GE & 2.64 & GE \\
\hline FACTOR MEAN & 2.77 & GE & 3.01 & GE & 2.94 & GE \\
\hline
\end{tabular}

$\mathrm{n}=26$

Legend:

$$
\begin{aligned}
& \text { Range } \\
& 3.26-4.00 \\
& 2.51-3.25 \\
& 1.76-2.50 \\
& 1.00-1.75
\end{aligned}
$$

$\underline{\text { Interpretation }}$

Very Great Extent (VGE)
Great Extent (GE)
Less Extent (LE)
Never (N)

It can be construed from the findings that the school maintains a system of giving due recognition for 
its people who perform well in their jobs. These some in the form promotions, cash gifts, certificates of appreciation and a lot more.

To a great extent the school uses the organizational structure to encourage effective followership as manifested by the composite mean of 3.19. It can be inferred from the finding that the school creates organizational situations where its people tend to adhere to organizational rules and policies willingly and with less resistance.

The subordinates (employees in Lyceum de Cebu to a great extent $(\mu=2.93)$ were allowed to participate in decision making on matters which affected them. For those concerns which have a direct or indirect impact on the various stakeholders in the school, they were involved in the process.

Corollary to the abovementioned findings, it shows that the employees in Lyceum de Cebu were empowered to a great extent $(\mu=2.64)$ to make work related decisions within the prescribed limits. This is a manifestation of the school's goal of letting everybody feel that all of them play a vital role to sustain the school's operations.

Lastly, the composite mean of 2.64 indicated that the school to a great extent solicited all the school members' inputs before final decisions were made. This in essence is to uphold the doctrine of participative management style which was observed in the school.

\subsection{Control Functions}

Results pertaining the extent to which control practices were espoused in the school are reflected in table 4. The factor mean of 3.12 obtained from the group mean of 3.03 for the teaching staff and 3.21 from the non-teaching staff shows that control practices are implemented to a great extent in Lycem de Cebu.

Specifically, the composite mean of 3.00 reveals the fact that to a great extent, the school measured performance of all its stakeholders based on the standards set.

Table4. Control Functions

\begin{tabular}{|c|c|c|c|c|c|c|}
\hline \multirow[b]{2}{*}{ INDICATORS } & \multicolumn{2}{|c|}{ Teaching Staff } & \multicolumn{2}{|c|}{ Non-Teaching Staff } & \multicolumn{2}{|c|}{ Composite } \\
\hline & Mean & Int. & Mean & Int. & Mean & Int. \\
\hline $\begin{array}{l}\text { 1. Measuring performance based on the } \\
\text { standards set by the school. }\end{array}$ & 3.00 & GE & 3.00 & GE & 3.00 & GE \\
\hline $\begin{array}{l}\text { 2. Requiring every department to prepare } \\
\text { reports and budgets or activities conducted. }\end{array}$ & 2.90 & GE & 3.33 & VGE & 3.12 & GE \\
\hline $\begin{array}{l}\text { 3. Defining standards of performance for all } \\
\text { functions done in the school. }\end{array}$ & 3.05 & GE & 2.90 & GE & 2.98 & GE \\
\hline $\begin{array}{l}\text { 4. Implementing corrective action or } \\
\text { deviations committed. }\end{array}$ & 3.05 & $\mathrm{GE}$ & 3.00 & GE & 3.03 & GE \\
\hline $\begin{array}{l}\text { 5. Administering disciplinary actions to erring } \\
\text { employees in a fair and objective manner. }\end{array}$ & 3.15 & GE & 3.33 & VGE & 3.24 & GE \\
\hline $\begin{array}{l}\text { Involving various school members in } \\
\text { reviewing the school's ongoing operations. }\end{array}$ & 3.00 & GE & 3.67 & VGE & 3.34 & VGE \\
\hline FACTOR MEAN & 3.03 & GE & 3.21 & GE & 3.12 & GE \\
\hline
\end{tabular}

$\mathrm{n}=26$

Legend:

$$
\begin{aligned}
& \text { Range } \\
& 3.26-4.00 \\
& 2.51-3.25 \\
& 1.76-2.50 \\
& 1.00-1.75
\end{aligned}
$$

Interpretation
Very Great Extent (VGE)
Great Extent (GE)
Less Extent (LE)
Never (N)

It can be assumed from the data that the school establishes of a systematic process through which the administration can regulate all organizational related activities.

All the various departments and units in the school to a great extent $(\mu=3.12)$ were required to prepare 
reports and budgets for activities performed. This was done to ensure that the targets set are met, expenditures and results are monitored and changes can be made when needed.

To a great extent $(\mu=2.98)$, standards of performance for all functions to a great extent were defined in the school. This was done to ensure full cooperation and compliance among all the employees to attain the goals set.

Whenever deviations were committed, corrective actions were implemented to a great extent as exhibited by the composite mean of 3.03. When certain infractions were done by the employees, the administration adopted remedial measures whenever if needed to rectify the weaknesses.

Whenever employees erred, disciplinary actions were administered to a great extent in a fair and objective manner $(\mu=3.24)$. This implied the fact that when employees were found to have committed violations in terms of the standards set, they were given the opportunity to answer the charges before any disciplinary measure was implemented.

The composite mean of 3.14 shows that to a very great extent, the various school members were involved in reviewing the school's ongoing operations. In the spirit of teamwork and cooperation, a core group of school employees representing a certain sector is convened to go over the school's various projects.

\title{
4.5. Summarized Data on the Extent of Management Functions
}

The summarized data on the extent to which the basic management functions were manifested in Lyceum de Cebu are exhibited in table 5. The general mean of 3.17 taken from the group mean of 3.02 from the teaching staff and 3.32 from the non-teaching staff shows that the practices relating to the said functions were adopted in Lyceum de Cebu to a great extent.

Specifically, the school in all cases $(\mu=3.41)$ prepared a blueprint through the planning process the goals and the means for achieving them. This function was not performed only by the top people but it is cascaded to all sectors in the school's hierarchy.

Table5. Summarized Data on the Management Functions

\begin{tabular}{|c|c|c|c|c|c|c|}
\hline \multirow[b]{2}{*}{ INDICATORS } & \multicolumn{2}{|c|}{ Teaching Staff } & \multicolumn{2}{|c|}{ Non Teaching Staff } & \multicolumn{2}{|c|}{ Factor Mean } \\
\hline & $\mu$ & Int. & $\mathbf{M}$ & Int. & $\boldsymbol{\mu}$ & Int. \\
\hline 1. Planning & 3.21 & GE & 3.61 & VGE & 3.41 & VGE \\
\hline 2. Organizing & 3.08 & GE & 3.34 & VGE & 3.21 & GE \\
\hline 3. Leading & 2.77 & GE & 3.11 & $\mathrm{GE}$ & 2.94 & GE \\
\hline 4. Controlling & 3.03 & GE & 3.21 & $\mathrm{GE}$ & 3.12 & GE \\
\hline GENERAL MEAN & 3.02 & GE & 3.32 & VGE & 3.17 & GE \\
\hline
\end{tabular}

$\mathrm{n}=26$

Legend:

$$
\begin{aligned}
& \text { Range } \\
& 3.26-4.00 \\
& 2.51-3.25 \\
& 1.76-2.50 \\
& 1.00-1.75
\end{aligned}
$$

\author{
Interpretation \\ Very Great Extent (VGE) \\ Great Extent (GE) \\ Less Extent (LE) \\ Never $(\mathrm{N})$
}

With regard to the organizing function its related practices were applied to a great extent $(\mu=3.21)$ in terms of creating a structure. This served as the framework where top management can provide the means of coordinating people, technology and institutional resources to attain the school's goals and objectives.

The factor means of 2.94 shows that the administration of Lyceum de Cebu to a great extent exemplified and reinforced not only authority but most importantly guided the people in the school toward the realization of its goals. The heads/administrators built widespread commitment among their subordinates to attain the school's objectives and stimulate the people to pursue high performance. 


\subsection{Assessment of the Extent of manifestation by the Respondents on the management Functions}

The assessments made by the teaching and non-teaching personnel as to the extent of manifestation of the implementation of the management functions in Lyceum

Table6. Assessment on the Extent of manifestation of the Implementation of the management functions

\begin{tabular}{|l|c|c|c|c|c|c|}
\hline \multirow{2}{*}{\multicolumn{1}{c|}{ INDICATORS }} & \multicolumn{2}{|c|}{ Teaching Staff } & \multicolumn{2}{c|}{ Non Teaching Staff } & \multicolumn{2}{c|}{ Factor Mean } \\
\cline { 2 - 7 } & $\boldsymbol{\mu}$ & Int. & $\mathbf{M}$ & Int. & $\boldsymbol{\mu}$ & Int. \\
\hline 1. Planning & 3.21 & GE & 3.61 & VGE & 3.41 & VGE \\
\hline 2. Organizing & 3.08 & GE & 3.34 & VGE & 3.21 & GE \\
\hline 3. Leading & 2.77 & GE & 3.11 & GE & 2.94 & GE \\
\hline 4. Controlling & 3.03 & GE & 3.21 & GE & 3.12 & GE \\
\hline GENERAL MEAN & 3.02 & GE & 3.32 & VGE & 3.17 & GE \\
\hline
\end{tabular}

$\mathrm{n}=26$

Legend:

$$
\begin{gathered}
\underline{\text { Range }} \\
3.26-4.00 \\
2.51-3.25 \\
1.76-2.50 \\
1.00-1.75
\end{gathered}
$$

$\underline{\text { Interpretation }}$

Very Great Extent(VGE)

Great Extent(GE)

Less Extent(LE)

Never(N)

de Cebu revealed that in terms of the planning and organizing functions, both were manifested to a great extent by the teaching staff and to a very great extent by the non-teaching staff, respectively. In terms of leading and controlling functions, these were both manifested to a great extent by the two group of respondents.

\section{Test of Differences}

The results of the Fisher's t-test of differences between the means of the two groups showed that there were no significant differences in the assessments made by the teaching and non-teaching personnel on the extent to which the following management functions were manifested in Lyceum de Cebu.

Based on the findings of the study, the researcher designed a proposed scheme to enhance the management functions and effectiveness of the organizational communication patterns of Lyceum de Cebu.

\section{CONCLUSION}

In the light of the findings of the study, the proponent concludes that even though the school was able to implement sound management practices all throughout the hierarchy, still, there are certain areas where improvements can be made.

\section{RECOMMENDATIONS}

Taking into account the findings of the study, the researcher recommends that:

- The proposed enhancement program entitled competitive advantage through transformation management (Appendix 1) be considered for implementation by the administration of Lyceum de Cebu.

- The administrators and subordinates collaborate with each other to ensure the successful implementation of the proposed program.

- The schemes used for evaluating the program proposed in this study be reviewed periodically to serve its purpose.

It is also recommended that future researchers may consider for further study the following topics:

- School Effectiveness, Accountability and Improvement in Lyceum de Cebu: Basis for Redirection. 
- Transformational Leadership, Shared Decision Making and Problem Solving Among the head of Lyceum de Cebu: Agenda for Development.

- Power and Politics in Lyceum de Cebu: Basis for a Rationalization Program.

\section{REFERENCES}

[1] Alday, Ramon J. and Timothy M. Stearns. Management, $19^{\text {th }}$ Edition., Cincinnati, Ohio: Southwestern Publishing, 2006.

[2] Certo, Samuel C. Modern Management. 10 $0^{\text {th }}$ Edition. Upper Saddle River, N.J.: Prentice Hall Inc., 2006.

[3] Campling, John, David Poole, et.al. Management. Queensland, Australia: John Wiley and Sons Australia, Ltd., 2006.

[4] Daft, Richard L. Management. $8^{\text {th }}$ Edition. Singapore: Southwestern, 2008.

[5] Davis, Mangant R. and David A. Weckler. A Practical Guide to Organizational Design. $4^{\text {th }}$ Edition Menlo Park, CA: Crisp Publications, 2006.

[6] Dumler, Michael P. and Steven J. Skinner. A Primer for Management. Mason OH: Thomson-Southwester, 2008.

[7] Fullan, M. The Meaning of Educational Change. $2^{\text {nd }}$ Edition. New York: Teacher College Press, 2006.

[8] Galbraith, Jay R. Designing Organizations: An Executive Guide to Strategy Structure and Process. $2^{\text {nd }}$ Edition, San Francisco, CA: Jossey -Bass, 2006.

[9] Hackman, Ricahrd J. and Greg R. Oldham. Work Redesign. $9^{\text {th }}$ Edition. Reading, MA: Addison - Wesley, 2004.

[10] Jones, Harry. Preparing Company Plans: A Workbook for Effective Corporate Planning. ${ }^{\text {th }}$ Edition. New York: Wiley and Sons, June 2005.

[11] Mockler, Robert J. Readings in Management Control. $12^{\text {th }}$ Edition. New York: Appleton - Century Crafts, 2001.

[12] Mooney, J. Ideas and Issues in Public Administration. $10^{\text {th }}$ Edition. New York: McGraw-Hill, 2004.

[13] Rue, Leslie W. and Lloyd Byars. Management Skills and Application. $4^{\text {th }}$ Edition. Boston, MA: McGrawHill, 2005

[14] Senge, Peter et. al. The Dance of Change: The Challenges to Sustaining Momentum in Learning Organizations. $3^{\text {rd }}$ Edition. New York: Doubleday, 2007.

[15] Yuki, Gary A. Leadership in Organizations. 10 ${ }^{\text {th }}$ Edition. Englewood Cliffs, New Jersey: Prentice Hall, 2002.

\section{APPENDIX 1}

\section{Proposal for Enhancement}

This chapter presents the proposals for enhancing the management practices of Lyceum de Cebu. In the process of formulating the proposals, the proponents take into account the results of the study which revealed that although the various management functions were manifested to a great extent yet, improvements can be done to sustain such conditions.

\section{Program Management}

This part highlights the strategies for implementing the proposed enhancements which are intended to improve the implementation of the basic management functions of the Lyceum de Cebu.

\section{Program Title}

This program is going to be called "Competitive Advantage through Transformational Management" (CATTM).

\section{Program Description}

This program involves a series of activities oriented toward implementing positive changes in the implementation of the various aspects of the basic management functions. This consist series of meetings to come up with refine practice. It will be participated by a core group of people.

\section{Rationale}

Organizational effectiveness now plays such a central role in the theory and practice of education that a thorough understanding of the concept is essential. From a social system perspective, effectiveness is not one theory but is comprised of indicators from inputs or resources from the environment, harmony among and quality of the school organization's transformational components, and the relative attainment of feasible standards that can be exchanged for other resources and incentives. 
To improve school effectiveness and loosen the constraints, there should be a coherent systematic approach to educational reform. Lyceum de Cebu cognizant of this dictum tries to establish systems of improvement using a set of critical environmental, transformational and performance outcome variables. The critical components of the model include a unifying vision in transforming internal processes and structures such as the management functions to maximize school effectiveness.

Lyceum de Cebu in its desire to become an effective learning organization, continuously strives to find ways to create structures that enhance organizational adaptation; create a school climate that is open, collaborative and self regulating while at the same time attracting people who are amenable to change. Hence, this program is intended to build a school that has the capacity to respond effectively not only to contemporary problems but also to new and emerging issues of school effectiveness.

\section{Program Objectives}

After the implementation of the program, the participants are expected to:

- Understand how each stakeholder of the school can create competitive advantage though effective internal processes and structures.

- Internalize the importance of the four management functions and the various types of activities associated with each type.

- Be familiar with the various strategies that can help the school adapt to an uncertain environment.

- Identify how structure can be used to achieve the school's strategic goals.

Proposed Enhancement Scheme Mechanisms. The administration will convene a core group composed of the Vice-President for Academics and Administration, two teaching and one nonteaching personnel who will go over the existing practices and the recommended improvements proposed by the researcher. The meeting will be done for three consecutive days in April to avoid disrupting the work schedule of the personnel involved.

The proposed intervention scheme are as follows and are based on the findings of the study:

A. Planning

Data Base: Table 1 shows that the planning functions were manifested to a very great extent by the non-teaching staff and to a great extent by the teaching personnel. Hence, the intervention schemes are designed to enhance and sustain such practices.

\section{Recommended Intervention Schemes:}

- Revisit the vision, mission and goals of the school periodically in view of the changes in the internal and external environment.

- Implement systematic planning at all levels of the institution.

- Ensure the development of commitment to school goals by involving everybody in the planning process.

- Develop effective action plans to ensure the implementation of the various planned activities.

- Communicate strategic intent to all school stakeholders - both employees and external constituents.

\section{B. Organizing}

Data Base: The results in table 2 revealed that organizing functions were manifested to a very great extent by the non teaching staff and to a great extent by the teaching staff. The proposed schemes are intended to improve the existing practices and sustain them.

\section{Recommended Intervention Schemes:}

- Re-examine specific duties and responsibilities by conducting periodic job analysis and upgrade job description and specification.

- Create and maintain a structure that supports organizational strategy. 
- Consider and review the extent to which authority will be distributed among the different employees throughout the institution.

- Revisit and group jobs according to logical assignments either by specialization or by function.

\section{Leading Function}

Data Base: The results in table 3 showed that the leading function was manifested by both groups of respondents to a great extent. Hence, the proposed intervention schemes are intended to improve the existing practices.

\section{Proposed Intervention Schemes}

- Periodically revisit the compensation package to ensure that it is fair, just and competitive in view of the existing economic conditions.

- Intensify internal coping strategies like budgeting, preparing reports and others to overcome resistance to resources allocation restraints.

- Encourage shared decision making by empowering all employees to make decision.

- Implement group advisory when the opinions or inputs of the employees are solicited and the possible implications of the actions to be undertaken.

\section{Control Function}

Data Base: Table 4 highlights the extent to which the various components of the control function was implemented in Lyceum de Cebu. Both groups of respondents averred that these were manifested to a great extent. Thus, the proposed intervention schemes are recommended to enhance the existing practices.

\section{Proposed Intervention Schemes}

- Specify performance standards for the intended outcomes of each function.

- Review policies as guidelines for present and future actions.

- Implementing monitoring schemes to review ongoing activities.

- Formulate standards to correct deviations and implement corresponding sanctions for violations committed.

AppendixTable1. Test of Hypothesis on the Planning Function

\begin{tabular}{|c|c|c|c|c|c|c|}
\hline \multirow[b]{2}{*}{ INDICATORS } & \multicolumn{2}{|l|}{ Mean } & \multirow[b]{2}{*}{$\begin{array}{l}\text { t } \\
\text { computed }\end{array}$} & \multirow[b]{2}{*}{ t critical } & \multirow[b]{2}{*}{ Decision } & \multirow[b]{2}{*}{$\begin{array}{l}\text { Interpre- } \\
\text { tation }\end{array}$} \\
\hline & $\begin{array}{l}\text { Teaching } \\
\text { Staff }\end{array}$ & $\begin{array}{l}\text { Non Teaching } \\
\text { Staff }\end{array}$ & & & & \\
\hline $\begin{array}{l}\text { 1. Formulating the } \\
\text { school's objectives is } \\
\text { done and participated by } \\
\text { all sectors. }\end{array}$ & 3.20 & 3.33 & 1.7540 & 2.080 & Accept & $\begin{array}{l}\text { No } \\
\text { Significant } \\
\text { Difference }\end{array}$ \\
\hline $\begin{array}{l}2 . \quad \text { Articulating the } \\
\text { vision, mission and } \\
\text { goals of the school in a } \\
\text { clear statement. }\end{array}$ & 3.55 & 4.00 & 0.2435 & 2.080 & Accept & $\begin{array}{l}\text { No } \\
\text { Significant } \\
\text { Difference }\end{array}$ \\
\hline $\begin{array}{l}\text { 3. Clarifying the indiv } \\
\text { idual roles of all sectors of } \\
\text { the school leading to the } \\
\text { attainment of its goa ls. }\end{array}$ & 3.25 & 3.67 & 1.2596 & 2.080 & Accept & $\begin{array}{l}\text { No } \\
\text { Significant } \\
\text { Difference }\end{array}$ \\
\hline $\begin{array}{l}\text { 4. Identifying present } \\
\text { and future opportune } \\
\text { ities of the school and } \\
\text { how to take advantage } \\
\text { of them. }\end{array}$ & 3.10 & 3.67 & 1.2596 & 2.080 & Accept & $\begin{array}{l}\text { No } \\
\text { Significant } \\
\text { Difference }\end{array}$ \\
\hline $\begin{array}{l}\text { 5. Emphasizing intern al } \\
\text { and external factors in the } \\
\text { planning processs. }\end{array}$ & 3.00 & 3.33 & 0.04942 & 2.080 & Accept & $\begin{array}{l}\text { No } \\
\text { Significant } \\
\text { Difference }\end{array}$ \\
\hline
\end{tabular}


Assessment on the Management Practices among Teaching and Non-Teaching Staff of an Academic Institution Managed by a Primary Cooperative in the Philippines: The Case of Lyceum De Cebu

\begin{tabular}{|l|l|l|l|l|l|l|}
\hline $\begin{array}{l}\text { 6. Describing how the } \\
\text { plans will lead to the } \\
\text { realization of the goals } \\
\text { in a simple manner. }\end{array}$ & 3.15 & 3.67 & 0.7599 & 2.080 & Accept & $\begin{array}{l}\text { No } \\
\text { Significant } \\
\text { Difference }\end{array}$ \\
\hline
\end{tabular}

AppendixTable2. Test of Hypothesis on the Organizing Function

\begin{tabular}{|c|c|c|c|c|c|c|}
\hline \multirow[b]{2}{*}{ INDICATORS } & \multicolumn{2}{|c|}{ Mean } & \multirow[b]{2}{*}{$\begin{array}{c}\mathbf{t} \\
\text { computed }\end{array}$} & \multirow[b]{2}{*}{$\stackrel{\mathbf{t}}{\text { critical }}$} & \multirow[b]{2}{*}{ Decision } & \multirow[b]{2}{*}{$\begin{array}{l}\text { Interpre- } \\
\text { tation }\end{array}$} \\
\hline & $\begin{array}{l}\text { Teaching } \\
\text { Staff }\end{array}$ & $\begin{array}{c}\text { Non Teaching } \\
\text { Staff }\end{array}$ & & & & \\
\hline $\begin{array}{l}\text { 1. Structuring the human and } \\
\text { material resources to ensure } \\
\text { that they are consis tent with } \\
\text { the vision, miss ion and goals } \\
\text { of the school. }\end{array}$ & 2.90 & 3.67 & 1.7226 & 2.080 & Accept & $\begin{array}{c}\text { No } \\
\text { Significant } \\
\text { Difference }\end{array}$ \\
\hline $\begin{array}{l}2 \text { Defining duties and respo } \\
\text { nsibilities in a clear and } \\
\text { simple manner through the } \\
\text { provision of job description. }\end{array}$ & 3.25 & 3.33 & 1.4882 & 2.080 & Accept & $\begin{array}{l}\text { No } \\
\text { Significant } \\
\text { Difference }\end{array}$ \\
\hline $\begin{array}{l}\text { 3. Promoting the unity of } \\
\text { command. }\end{array}$ & 3.15 & 3.67 & 0.8849 & 2.080 & Accept & $\begin{array}{c}\text { No } \\
\text { Significant } \\
\text { Difference } \\
\end{array}$ \\
\hline $\begin{array}{l}\text { 4. Coordinating all activity } \\
\text { es and efforts in the school } \\
\text { in a synchronized manner. }\end{array}$ & 3.15 & 3.67 & 0.5209 & 2.080 & Accept & $\begin{array}{c}\text { No } \\
\text { Significant } \\
\text { Difference }\end{array}$ \\
\hline $\begin{array}{l}\text { 5.Encouraging specialize } \\
\text { tion in the performance of a } \\
\text { specific task for each } \\
\text { employee }\end{array}$ & 3.05 & 3.00 & 0.2110 & 2.080 & Accept & $\begin{array}{l}\text { No } \\
\text { Significant } \\
\text { Difference }\end{array}$ \\
\hline $\begin{array}{l}\text { 6.Limiting the number of } \\
\text { employees being supervised } \\
\text { by a certain department head. }\end{array}$ & 2.95 & 2.67 & 0.2110 & 2.080 & Accept & $\begin{array}{l}\text { No } \\
\text { Significant } \\
\text { Difference }\end{array}$ \\
\hline
\end{tabular}

AppendixTable3. Test of Hypothesis on the Leading Function

\begin{tabular}{|c|c|c|c|c|c|c|}
\hline \multirow[b]{2}{*}{ INDICATORS } & \multicolumn{2}{|c|}{ Mean } & \multirow[b]{2}{*}{$\begin{array}{c}\mathbf{t} \\
\text { computed }\end{array}$} & \multirow[b]{2}{*}{$\begin{array}{c}\mathbf{t} \\
\text { critical }\end{array}$} & \multirow[b]{2}{*}{ Decision } & \multirow[b]{2}{*}{$\begin{array}{c}\text { Interpre- } \\
\text { tation }\end{array}$} \\
\hline & $\begin{array}{l}\text { Teaching } \\
\text { Staff }\end{array}$ & $\begin{array}{c}\text { Non Teaching } \\
\text { Staff }\end{array}$ & & & & \\
\hline $\begin{array}{l}\text { 1. Providing employees } \\
\text { with the necessary resour } \\
\text { ces that will help translate } \\
\text { efforts into performance. }\end{array}$ & 2.80 & 3.67 & 1.7226 & 2.080 & Accept & $\begin{array}{l}\text { No } \\
\text { Significant } \\
\text { Difference }\end{array}$ \\
\hline $\begin{array}{l}\text { 2. Maintaining a reward } \\
\text { system that gives due } \\
\text { recognition to exemplary } \\
\text { performance. }\end{array}$ & 2.70 & 3.33 & 1.4882 & 2.080 & Accept & $\begin{array}{l}\text { No } \\
\text { Significant } \\
\text { Difference }\end{array}$ \\
\hline $\begin{array}{l}\text { 3. Using the organization } \\
\text { nal structure to encourage } \\
\text { effective followership. }\end{array}$ & 3.05 & 3.33 & 0.8849 & 2.080 & Accept & $\begin{array}{c}\text { No } \\
\text { Significant } \\
\text { Difference }\end{array}$ \\
\hline $\begin{array}{l}\text { 4. Allowing subordinates } \\
\text { to participate in decision } \\
\text { making on matters which } \\
\text { affect the former. }\end{array}$ & 2.85 & 3.00 & 0.5209 & 2.080 & Accept & $\begin{array}{l}\text { No } \\
\text { Significant } \\
\text { Difference }\end{array}$ \\
\hline $\begin{array}{lrr}5 . & \text { Empowering } \\
\text { employees to } & \text { make } \\
\text { decisions } & & \text { within } \\
\text { prescribed limits. } & \end{array}$ & 2.60 & 2.67 & 0.2110 & 2.080 & Accept & $\begin{array}{c}\text { No } \\
\text { Significant } \\
\text { Difference }\end{array}$ \\
\hline $\begin{array}{l}\text { 6. Soliciting all the } \\
\text { school members' inputs } \\
\text { before final decisions }\end{array}$ & $2 . .60$ & 2.67 & 0.2110 & 2.080 & Accept & $\begin{array}{l}\text { No } \\
\text { Significant } \\
\text { Difference } \\
\end{array}$ \\
\hline
\end{tabular}


Assessment on the Management Practices among Teaching and Non-Teaching Staff of an Academic Institution Managed by a Primary Cooperative in the Philippines: The Case of Lyceum De Cebu

AppendixTable4. Test of Hypothesis on the Controlling Function

\begin{tabular}{|l|c|c|c|c|c|c|}
\hline \multicolumn{1}{|c|}{ INDICATORS } & $\begin{array}{c}\text { Teaching } \\
\text { Staff }\end{array}$ & $\begin{array}{c}\text { Non Teaching } \\
\text { Staff }\end{array}$ & $\begin{array}{c}\text { t } \\
\text { computed }\end{array}$ & $\begin{array}{c}\text { t } \\
\text { critical }\end{array}$ & Decision & $\begin{array}{c}\text { Interpre- } \\
\text { tation }\end{array}$ \\
\cline { 2 - 6 } $\begin{array}{l}\text { 1. Measuring performance } \\
\text { based on the standards set } \\
\text { by the school. }\end{array}$ & 3.00 & 3.00 & 0 & 2.080 & Accept & $\begin{array}{c}\text { No } \\
\text { Significant } \\
\text { Difference }\end{array}$ \\
\hline $\begin{array}{l}\text { 2. Requiring every depart } \\
\text { ment to prepare reports } \\
\text { and budgets or activities } \\
\text { conducted. }\end{array}$ & 2.90 & 3.33 & 1.1023 & 2.080 & Accept & $\begin{array}{c}\text { No } \\
\text { Significant } \\
\text { Difference }\end{array}$ \\
\hline $\begin{array}{l}\text { 3. Defining standards of } \\
\text { performance for all functi } \\
\text { onns done in the school. }\end{array}$ & 3.05 & 2.90 & 0.8849 & 2.080 & Accept & $\begin{array}{c}\text { No } \\
\text { Significant } \\
\text { Difference }\end{array}$ \\
\hline $\begin{array}{l}\text { 4.Implementing corrective } \\
\text { action or deviations com } \\
\text { mitted. }\end{array}$ & 3.05 & 3.00 & 0.1663 & 2.080 & Accept & $\begin{array}{c}\text { No } \\
\text { Significant } \\
\text { Difference }\end{array}$ \\
\hline $\begin{array}{l}\text { 5. Administering } \\
\text { disciplinary actions to } \\
\text { erring employees in a fair } \\
\text { and objective manner. }\end{array}$ & 3.15 & 3.33 & 0.5051 & 2.080 & Accept & $\begin{array}{c}\text { No } \\
\text { Significant } \\
\text { Difference }\end{array}$ \\
\hline $\begin{array}{l}\text { 6. Involving various } \\
\text { school members in } \\
\text { reviewing the school's } \\
\text { ongoing operations. }\end{array}$ & 3.00 & 3.67 & 0.9555 & 2.080 & Accept & $\begin{array}{l}\text { No } \\
\text { Significant } \\
\text { Difference }\end{array}$ \\
\hline
\end{tabular}

\section{AUTHOR'S BIOGRAPHY}

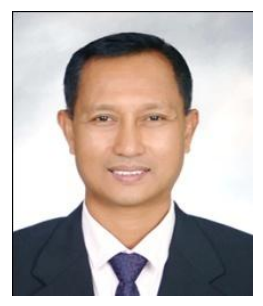

Asterio T. Miranda, Jr. is an associate professor of the Department of Taxation, College of Business Administration of Keimyung University(KMU), South Korea. $\mathrm{He}$ Holds a doctorate degree in Extension Education, with Agribusiness Management as cognate, from the University of the Philippines at Los Banos (UPLB), Laguna, Philippines. He graduated from the University of Eastern Philippines both for his Master in Business Administration, and Bachelor of Science in Business Administration degrees.

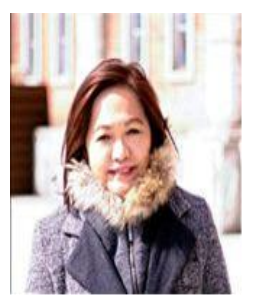

Juneth Lourdes Fiel-Miranda is a certified public accountant ( CPA) and an associate professor of accounting and other business related subjects at Keimyung Adams College (KAC) of the Keimyung University in South Korea. She has been an associate professor at the Catholic University of Daegu, South Korea, teaching accounting courses. She graduated with distinction from Western Leyte College for her undergraduate degree in Commerce, and received her Master in Business Administration (MBA) degree from the University of Eastern Philippines, and finished her Doctorate degree in Management major in Human Resources Management at the University of San Jose Recoletos, Cebu City, Philippines.

Citation: Juneth Lourdes Fiel-Miranda, Asterio T. Miranda. “Assessment on the Management Practices among Teaching and Non-Teaching Staff of an Academic Institution Managed by a Primary Cooperative in the Philippines: The Case of Lyceum De Cebu" International Journal of Managerial Studies and Research (IJMSR), vol 6, no. 10, 2018, pp. 1-18. doi: http://dx.doi.org/10.20431/2349-0349.0610001.

Copyright: (c) 2018 Authors. This is an open-access article distributed under the terms of the Creative Commons Attribution License, which permits unrestricted use, distribution, and reproduction in any medium, provided the original author and source are credited. 